\title{
Spawning, intracapsular development and production potential of viable juveniles of a murex Chicoreus virgineus var. ponderosa Sowerby under laboratory conditions
}

\author{
I. Jagadis ${ }^{*}$, K. Shunmugasundaram, Md. Sathakkathulla, T. Mohanraj \\ Tuticorin Research Centre of CMFRI, South Beach Road, Tuticorin, India; *Corresponding Author: ijagadis@sify.com \\ Received 18 March 2013; revised 19 April 2013; accepted 10 May 2013 \\ Copyright (C) 2013 I. Jagadis et al. This is an open access article distributed under the Creative Commons Attribution License, which \\ permits unrestricted use, distribution, and reproduction in any medium, provided the original work is properly cited.
}

\section{ABSTRACT}

Muricids are commercially important gastropods and are exploited primarily for shell craft industries. They also occupy a niche in ornamental keeping. Studies on the larval development of muricids in Indian waters are few. Hence, an attempt was made to study with a focus on the optimum requirements for captive brood maintenance; regional variation in egg laying, intracapsular development and to estimate production potential of individual brooder (the length/ weight ranged from $80-110 \mathrm{~mm} / 49-169 \mathrm{~g}$ (average $94.875 \pm 3.980 \mathrm{~mm} / 111.625 \pm 14.870 \mathrm{~g}$ ) of Chicoreus virgineus var. ponderosa collected off Tuticorin coast, Gulf of Mannar. Experimental airlift water circulation system fitted in 1 t FRP tanks having an overturn of $300 \%$ water is found suitable for long term maintenance and maturation of brooders with near cent percent survival over a year. Spontaneous breeding commenced from June'09. Eggs cases were "vase" shaped and measured $1.2-1.5 \mathrm{~cm}$ in height. Egg case numbers varied between 110 and 140 and got reduced to 10 - 40 during October and increased in Nov \& December. Number of eggs within the egg case was highly variable ranging from 100 380. Eggs were spherical, embedded in jelly mass within the egg case and measured 510 $608 \mu(578 \mu)$. Intra capsular development is detailed and compared with the earlier report on this species from other areas of Indian coast. Development took nearly 20 days and only few free living juveniles measuring between 1.7 - 1.9 $\mathrm{mm}$ emerged and the rest of the eggs have functioned as "Nurse eggs". Average net pro- duction potential of a single viable egg case was estimated to be 6.7 nos for Chicoreus virgineus var. ponderosa of Tuticorin coast of Gulf of Mannar.

Keywords: Spawning; Intra Capsular Development; Muricids; Chicoreus spp

\section{INTRODUCTION}

Muricids are commercially important gastropods and are exploited by fishermen for shell craft industries. Few species belonging to the genus Chicoreus are listed as endangered under Wild life Act 1972. In spite of this, a defined fishing pressure is exerted on these species due to specific collections by divers and also due to regular bye catch in bottom set gill nets directed for lobster and crab fishery in most of the landing centres of Gulf of Mannar.

The knowledge on the life cycle of most of the marine gastropods are lacking in India though they have considerable scientific and economic importance [1]. Few studies have been reported on buccinid gastropod Babylonia spirata, on spawning and larval development [2] and larval development and seed production [3]. Patterson et al. [1] has reported the feasibility of culturing spiral Babylon, Babylonia spirata in Tuticorin. Natarajan, 1957 [4], has studied and reported the egg mass and larval development of gastropods including C. virgineus from Palk Bay and GoM. The spawning season [5] and the larval development of Chicoreus ramosus from Portonovo waters has been reported by Ramesh et al. [6]. Experimental culture of $C$. virgineus off Portonovo coast was studied by Ramesh et al. [6].

In the present attempt focus was made to study the op- 
timum requirements for long term brood maintenance, regional variations in egg laying pattern, comparative intracapsular development and estimation of the production potential of specific size range of Chicoreus virgineus var. ponderosa a predator muricid, collected off Tuticorin in Gulf of Mannar. The information gained under this study would throw light on applying the results for developing a protocol for optimum brood stock collection and maintenance of similar endangered muricid gastropods for large scale seed production for conservation purpose.

\section{MATERIAL AND METHODS}

\subsection{Brood Stock Maintenance System and Spawning under Captive Condition}

Eight specimens of Chicoreus virgineus var. ponderosa length/weight ranging from 80 - $110 \mathrm{~mm}$ (94.875 \pm $3.980 \mathrm{~mm})$ and $49-165 \mathrm{~g}(111.625 \pm 14.870 \mathrm{~g})$ were held in a brood stock maintenance system for breeding during 2009.

The system essentially had one tonne fibre reinforced plastic (FRP) rectangular tank (length, width, height = $2.15 \times 1.2 \times 0.5 \mathrm{~m})$. The bottom of the tank was filled with thoroughly cleaned sand for $10 \mathrm{~cm}$ height. Air lift of water was effected by a perforated PVC rectangular pipe (dia “1.0”) frames all along the side of the tank with a vertical stand pipe at one corner. The PVC tube frame was woven with $0.5 \mathrm{~mm}$ mesh nylon bolting cloth. Continuous air supply was provided with an aquarium aeration tube inserted in the vertical standpipe which is connected to the lead pipe from a twin lobe air blower. The tanks were filled with water volume of 750 litre and covered with cotton black cloth for maintenance of 12:12 hr light/dark condition.

\subsection{Feeding Regimen}

The brooders were fed with live clams (Paphia malabarica) at 10 numbers (av. flesh weight $=2.0 \mathrm{~g}$ ) in each tank. The brooders tore open the shell of clams and fed on the flesh. The empty shells were removed and the number of clams fed such a way was recorded and equal number of live clams replaced thus arriving at the number of clams consumed/individual brooder/week.

Data on the egg laying habits, pattern of egg laying, numbers of egg cases laid in each spawning, size of the individual egg cases were noted individually for each of the marked females.

\subsection{Intracapsular Development and Production Potential}

The intra capsular egg development was carefully monitored measured and photographed at specific interval and visible developmental stages using a Labomed Binocular microscope at constant magnification. The egg cases were obtained from single cluster of eggs laid by a female and cut open to study the status of the eggs/larvae within for following the intra capsular development. The production potential of the brooders was estimated by hatching in duplicates of ten egg cases from 5 egg clusters in a glass culture container of 1 litre capacity with mild aeration. The egg cases were monitored for 20 days and within this period data collection were made on number of egg capsules hatched, unhatched and decayed. Observation was also made on the development of juveniles within the egg case but dead and emerged live juveniles.

\section{RESULTS}

\subsection{Brood Stock Maintenance and Spawning under Captive Condition}

The brood stock maintenance system developed in 1000 l FRP rectangular tank (water volume $=750$ l) with air lift system adjusted to effect $300 \%$ overturn of seawater per 24 hrs and a calculated average feed intake (live clams $=$ av. meat weight $=2.0 \mathrm{~g}$ ) observed was 3 nos/individual brooder/ week was very conducive for the survival and egg case laying of the brood $C$. virgineus. 100 percent survival was observed in the tanks for brooders maintained over a period of one year and the feed protocol was sufficient for maintaining the brooders healthy. Mating of $C$. virgineus was not observed during day time. Spontaneous breeding commenced from June 2009 and continued up to December 2009 and ceased later (Table 1). The female Chicoreus started laying egg cases one by one on the side surface of the brood stock tank and the egg case laying doesn't have any specific shape. The egg laying of individual females extended for 2 to 3 days and in some cases, interrupted egg laying

Table 1. Details of spawning under captive condition 2009.

\begin{tabular}{|c|c|c|c|c|c|c|c|c|c|c|c|c|}
\hline Months/brooders & Jan' 09 & Feb & Mar & Apr & May & June & Jly & Aug & Sep & Oct & Nov & Dec \\
\hline Female 1 & - & - & - & - & - & 110 & - & 115 & 100 & 40 & 110 & - \\
\hline Female 2 & - & - & - & - & - & 135 & 100 & 110 & 80 & 10 & 135 & 100 \\
\hline Female 3 & - & - & - & - & - & 140 & 90 & 85 & 90 & 30 & 140 & 90 \\
\hline
\end{tabular}


was also observed. The total number of egg cases laid ranged from 110 - 140 (June 2009) and decreased to 10 40 (October 2009) and again it increased during November \& December 2009. The individual egg cases were vasiform shape and measured $12-15 \mathrm{~mm}$ in length (Figure 1(b)). In all the occasion individual spawning was noticed and in no instance was communal egg case laying observed (Figure 1(a)).

Environmental parameters of the brood stock maintenance tank were monitored bimonthly and it fluctuated in the rearing containers and the water temperature ranged from $26.5^{\circ} \mathrm{C}$ to $29.9^{\circ} \mathrm{C}\left(27.908^{\circ} \mathrm{C} \pm 0.194^{\circ} \mathrm{C}\right)$, $\mathrm{pH}$ from 8.1 to $8.5(8.267 \pm 0.030)$ and salinity from 31.0 to 34.5 ppt (32.54 \pm 0.154$)$.

\subsection{Intracapsular Development}

Eggs of C. virgineus of Tuticorin coast, Gulf of Mannar are spherical in shape and the size measured between $510-608 \mu(578.3 \mu)$ in diameter. Each egg case was

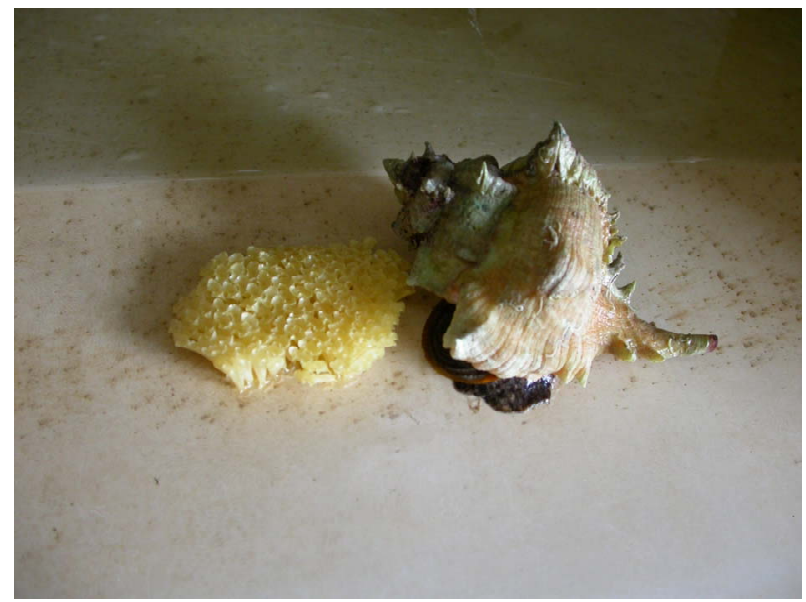

(a)

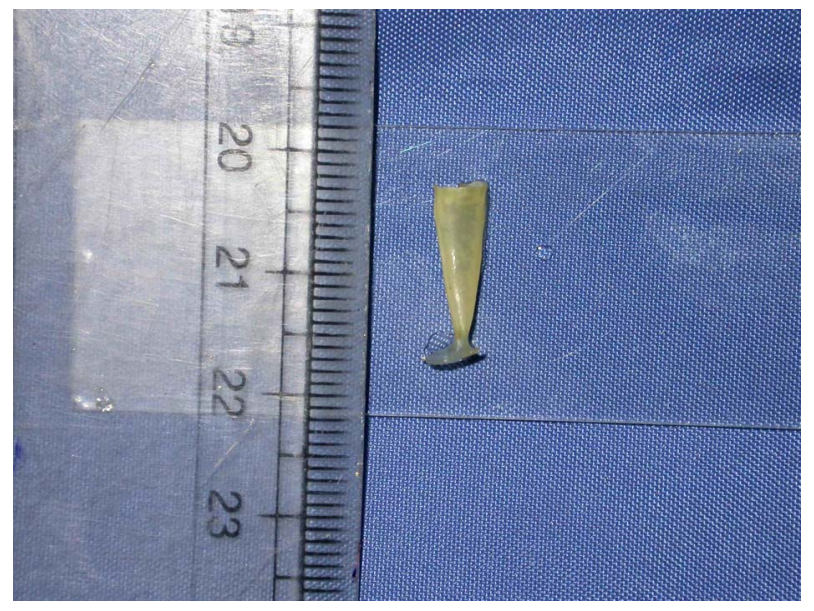

(b)

Figure 1. Individual spawning by Chicoreus virgineus var. ponderosa. (a) Spawning; (b) A single egg case. found to contain eggs ranging from 100 - 380 nos. The day 1 eggs had undifferentiated spherical cells compactly arranged within the cell wall and are found embedded in the jelly mass within the capsule (Figure 2(a)). First and second polar bodies formed within 6 hrs of spawning and the cleavage continued up to 2 days post spawning. On day 4 the terminal portion of the spherical egg started dividing further developing into two small velar lobes with cilia. On day 8 , the egg case contained majority of spherical eggs along with few early developing veligers. Though the early developing veligers had velum they are not freely motile (Figure 2(b)). On day 11, the veligers have further developed and the velum becomes active and four lobed (Figure 2(c)). The size of the veliger at this stage ranged from 948 to $1094 \mu(1019 \mu)$.

At this stage, it was very evident in two aspects i.e., there is a very clear difference in its size and activation and the presence of undifferentiated spherical egg. All these undifferentiated spherical eggs present in the egg case only suggest that these eggs serve as "Nurse eggs". On day 15 , the veligers transformed into early juvenile

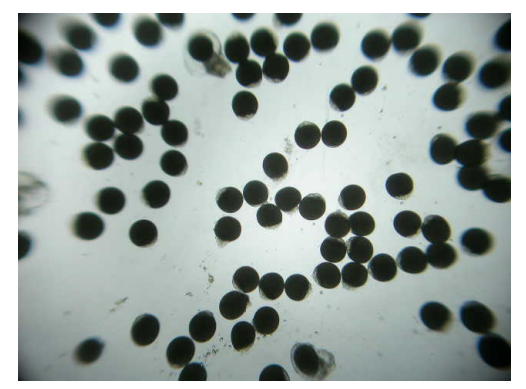

(a)

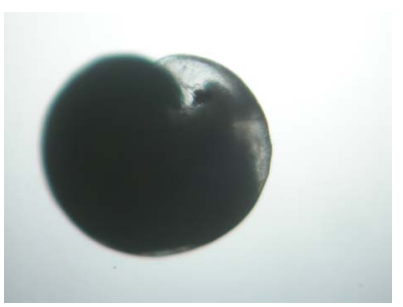

(b)

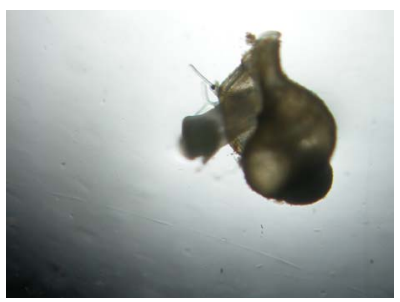

(d)

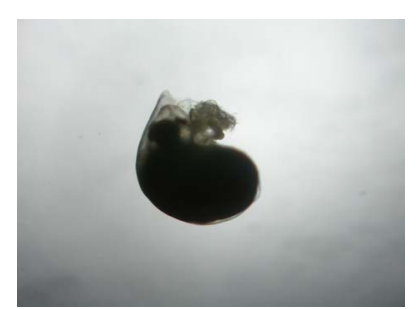

(c)

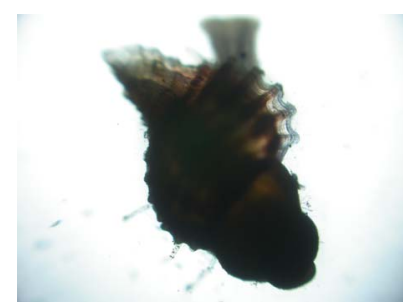

(e)
Figure 2. Sequence of intra capsular development in Chicoreus virgineus var. ponderosa (Figures 1(a)-(e)). (a) Eggs embedded in jelly; (b) Developing veliger; (c) Developed veliger; (d) Early juvenile; (e) Emerged juvenile. 
and they measured from 1361 - $1458 \mu(1405 \mu)$. The early juvenile shell had one whorl and prominent siphonnal canal, distinct foot and eye (Figure 2(d)). On day 20, they transformed completely into juveniles with two whorls and development of proboscis between the antennae and the foot has become functional by now. The fully developed juvenile muricids emerged out through the aperture on the top of the egg cases and actively crawling on the bottom of the culture containers. The size range of the free living juveniles ranged from 1652 to $1993 \mu(1827 \mu)$ and had 4 - 6 spiny outgrowths on the outer lip of the shell (Figure 2(e)).

\subsection{Estimation of Production Potential}

Data collected from the separately reared egg cases (nos $=100)$ for determining the production potential of viable juvenile muricids under laboratory conditions are given in Table 2. From the Table it is found that out of the 50 egg cases maintained in duplicate, hatching was successful only in 78. The rest of them were either un hatched or decayed. Out of a total of 601 fully developed juveniles obtained, 82 juveniles were born dead and only the rest 519 were viable. The average live juveniles from individual egg case ranged from 1.8 to 8.7. Thus the net potential juveniles expected to get recruited to the habitat is worked out to be 6.7 individual/each hatched egg case and the remaining eggs serve as "Nurse eggs".

\section{DISCUSSION}

In India, Muricids are exploited for commercial shell craft industries and the utility for common men as food has not that familiarized as in the case of Philippines where they are exploited for human consumption as well as aquarium pets. Antony S. Illano et al., [7] has described the egg laying habits of a muricid Hexaplex chicoreus as both communal and individual. D' Asaro (1986) [8] has reported communal spawning in $M$. fulvescens, Gohar and Eisawy (1967) [9] in M. incarnates. The egg laying habits of Chicoreus virgenius var. ponderosa studied now is individual in all the occasions. Saglam and Duzgunes (2007) [10] have observed the egg laying season for Rapana venosa as mid June to August. Ramesh et al. (1994) [6] has stated the spawning season of $C$. virgineus as February-April of Portonovo coast. In contrary, the season commences in mid June and extends up to December as observed in the present study.

The shape of the egg case was vasifom in the present study as reported for $C$. ramosus [11], [6] and $M$. florites [8], and the length of the egg case ranged from 12 $15 \mathrm{~mm}$ which is comparable to that observed for the same species in Portonovo coast which is 12.1 - $13.4 \mathrm{~mm}$ [6]. The number of egg cases laid per brooder was observed for $C$. virgineus of Tuticorin coast, Gulf of Mannar in the present study as 110 - 140 which was well above the numbers observed for Portonovo coast which is 42 - 98 [6] whereas the numbers observed in the case of Rapana venosa in Southeastern Black sea is much higher i.e., 197 999 [10]. Ramesh, 1994, [6] has estimated the number of eggs as 534 - 596 in C. virgineus of Portonovo coast which is much higher than that of 100 - 380 eggs observed for C. virgineus of Tuticorin coast, Gulf of Mannar, however, the egg size ranging from 192 - $210 \mu$ was far smaller when compared to the egg size of 510 - $608 \mu$ observed for Tuticorin coast. This could be attributed to the size difference of the eggs produced by the brooders of these two geographical regions though the brood size is almost similar. Purchon, 1968 [12] has attributed the difference in the number of eggs in the capsule to the

Table 2. Details of the results of egg case rearing for assessing the production potential of individual brooder.

\begin{tabular}{|c|c|c|c|c|c|c|}
\hline \multirow{2}{*}{$\begin{array}{l}\text { Trial } \\
\text { No. }\end{array}$} & \multirow{2}{*}{ No. of egg case } & \multicolumn{3}{|c|}{ Status of egg case after 20 days } & \multicolumn{2}{|c|}{ Developed juveniles } \\
\hline & & Hatched & Unhatched & Decayed & Dead & Live \\
\hline 1 & 10 & 7 & 3 & 0 & 8 & 18 \\
\hline 2 & 10 & 10 & 0 & 0 & 0 & 46 \\
\hline 3 & 10 & 9 & 0 & 1 & 0 & 24 \\
\hline 4 & 10 & 7 & 0 & 3 & 15 & 51 \\
\hline 5 & 10 & 6 & 1 & 3 & 8 & 29 \\
\hline $1 \mathrm{a}$ & 10 & 6 & 1 & 3 & 0 & 65 \\
\hline $2 \mathrm{a}$ & 10 & 7 & 0 & 3 & 0 & 31 \\
\hline За & 10 & 9 & 0 & 1 & 0 & 87 \\
\hline $4 a$ & 10 & 8 & 0 & 2 & 8 & 86 \\
\hline $5 a$ & 10 & 9 & 1 & 0 & 23 & 87 \\
\hline
\end{tabular}


size of the parent individual whereas Webber, 1977 [13] to availability of food and environmental parameters.

The incubation period for the present observations on C. virgineus is 20 days which is relatively shorter as compared to C. virgineus of Portonovo coast which is 26 days [6]. Morton, 1987 [14] has stated that the residence time and the size of the hatching are possibly related to the nutritional resources of the capsule contents. The hatching size of $C$. virgineus off Portonovo coast was $1210-1340 \mu$ [6] which is much lesser than the present study (1652 to $1895 \mu$ ). Shanmugaraj, 1994 [2] has further stated that the newly hatched juvenile takes $48 \mathrm{hrs}$ for fully metamorphosing as against the observations of the present study where, the released juveniles are already metamorphosed which is clearly evident by their size difference.

Saglam and Duzgunes 2007 [10] has observed that development of $R$. venosa embryos are without "Nurse eggs" whereas in the present observation the number of developed juveniles that emerges out after incubation period was much less than the number of eggs that each egg case contains firmly suggest the role of the remaining eggs as "Nurse eggs". Ramesh, 1994 [6] has mentioned that the hatching rates of $C$. virgineus of Portonovo coast as 15 on an average, and Stella, 1995 [15] has observed the number of embryos at the time of hatching per capsules ranged from 10 - 45 and all these data only vaguely indicates the number and it is comparatively higher to that estimated in the present study.

The current study has experimentally proved that though the individual brooder lay more number of egg cases in a spawning and each egg case containing varied number of eggs, the net potential juveniles that gets recruited to the habitat is estimated to be 6.7 individual/each hatched egg case and the remaining eggs serve as "Nurse eggs" in the case of $C$. virgineus var. ponderosa of Tuticorin Coast, Gulf of Mannar.

\section{ACKNOWLEDGEMENT}

The authors are thankful to Dr. G. Syda Rao, Director, CMFRI, Kochi for his encouragement. Sincere thanks to Dr. G. Gopakumar, Head, Mariculture Division, MRC of CMFRI, Mandapam Camp and Dr. Sunil K. Mohamed, Head, Molluscan Fisheries Division, Kochi for their valuable suggestions and guidance. Thanks are also due to The Scientist in Charge, TRC of CMFRI for facilities to carry out the work. Assistance rendered by Shri N. Jesuraj and Shri. Sekar V Rayer, Skin Divers in collection of brood animals is gratefully acknowledged.

\section{REFERENCES}

[1] Edward, J.K.P., Selvam, B.A.P. and Renitta, R.E. (2006) Studies on the status of culturing spiral Babylon, Babylonia spirata in Tuticorin, Southeastern India. Coastal Ma- rine Science, 30, 443-452.

[2] Shanmugaraj, T., Murugan, A. and Ayyakkannu, K. (1994) Laboratory spawning and larval development of Babylonia spirata (L.) (Neo gastropoda: Buccinidae). Phuket. Mar. Biol. Cent. Spl. Publn. 13, 95-97.

[3] Sreejaya, R., Mohan, A., Laxmilatha, P. and Appukuttan, K.K. (2004) Larval development and seed production in the "whelk" Babylonia spirata. Journal of Marine Biological Association of India, 46, 64-72.

[4] Natarajan, A.V. (1957) Studies on the egg masses and larval development of some Prosobranchs from the Gulf of Mannar and the Palk Bay. Proceedings of the Indian Academy of Sciences, 46, 170-228.

[5] Ramesh, M., Xavier, J.K., Paterson Edward and Ayyakannu, K. (1992) Reproductive biology of Chicoreus ramosus from Mandapam coastal waters, southeast coast of India. Phuket Mar. Biol Cent. Spl. Publn., 10, 80-85.

[6] Ramesh, M., Xavier, J.K., Paterson, E. and Ayyakannu, K. (1994) Experimental culture of Chicoreus virgineus (Roading, 1798). Phuket Mar. Mar. Biol Cent. Spl. Publn., 10, 99-102.

[7] Antony, S.I., Alexis, M.C., Donabelle, C. and Rome, D. (2007) Egg laying and intracapsular development of a Murex shell Hexaplex chicoreus under laboratory conditions. Asian Pacific Aquaculture, Hanoi.

[8] D’ Asaro, C.N. (1986) Egg capsules of eleven marine prosobranchs from northwest Florida. Bulletin of Marine Science, 39, 76-91.

[9] Gohar, H.A.F and Eisway, A.M. (1967) The egg masses and development of five Rachiglossan prosobranchs (from the red sea). Pub.mar.bio. St. Ghardaqa, Red sea, 14, 215-268.

[10] Saglam, H. and Duzgunes, E. (2007) Deposition of egg capsule and larval development of Rapana venosa (Gastropoda: Muricidae) from the south-eastern Black sea.

[11] Bussarawit, N. and Ruangchua, T. (1991) The production and morphology of egg capsules and veliger larvae of Chicoreus ramosa. Phuket Mar.Biol.Cent.Spl.Publ., 9, 7074.

[12] Purchon, R.D. (1968) The biology of the mollusca. Pergamon Press, Oxford.

[13] Webber, H.H. (1977) Gastropoda: Prosobranchia. In: Giese, A.C. and Pearse, J.S., Eds., Reproduction of $\mathrm{Ma}-$ rine Invertebrates. Vol. IV. Molluscs: Gastropods and Cephalopods, Academic Press, New York, 1-97.

[14] Morton, B. (1987) Juvenile growth of the South China Sea whelk Hemifusus tuba (Gmelin) (Prosobranchia: Melongenidae) and the importance of sibling cannibalism in estimates of consumption. Journal of Experimental Marine Biology and Ecology, 109, 1-14.

[15] Stella, C. (1995) Studies on the taxonomy and eco biology of Chicoreus species (Class: Gastropoda, Family: Muricidae) from Parangipettai waters, Southeast Coast of India. Ph.D. Thesis, Annamalai University, Chidambaram. 